\title{
PHYSIOLOGICAL QUALITY OF WHEAT SEEDS SUBMITTED TO SALINE STRESS
}

\author{
GISELALOUREIRODUARTE², NEI FERNANDESLOPES ${ }^{3}$, DARIO MUNTDE MORAES ${ }^{4}$, RODRIGO NASCIMENTODASILVA ${ }^{5}$
}

\begin{abstract}
The objective of this experiment was to determine the influence of different salt levels (zero, $15,30,45$ and $60 \mathrm{mM} \mathrm{NaCl}$ ) on seed physiological quality of two wheat cultivars (BRS 177 and BRS 179). SUMMARIZE METHODOLOGY. The results allow the following conclusions: the physiological quality (germination and vigor) of wheat seeds, cultivars BRS 179 and BRS 177, decrease with the increase of the salinity. The wheat seeds cv. BRS 179 performs better than BRS 177 , mainly in higher salt concentrations $\left({ }^{3} 45 \mathrm{mM}\right.$ of $\left.\mathrm{NaCl}\right)$. The electric conductivity of wheat seeds increases in function of the increment of the saline concentrations.
\end{abstract}

Index terms: Triticum aestivum, germination, vigor, salt.

\section{QUALIDADE FISIOLÓGICADE SEMENTES DE TRIGO SUBMETIDAS AO ESTRESSE SALINO}

\begin{abstract}
RESUMO - O objetivo do experimento foi determinar a influência de diferentes níveis de sal (zero, $15,30,45$ e $60 \mathrm{mM}$ de $\mathrm{NaCl}$ ) sobre a qualidade fisiológica de duas cultivares de trigo (BRS 177 e BRS 179). A germinação e a velocidade de germinação de sementes de trigo decresceram com aumento da salinidade, reduzindo a viabilidade e o vigor destas. A salinidade afetou a integridade das membranas, principalmente da cv. BRS 177 que mostrou mais sensibilidade ao estresse salino.
\end{abstract}

Termos para indexação: Triticum aestivum, germinação, vigor, sal.

\section{INTRODUCTION}

The way the seeds manipulate environment signals to determine the best moment to initiate radicle emergence and posterior development of seedlings is a basic question in the physiology of germination. This is a critical fact for seeds, since seedling survival rate depends on water availability in the environment (Bradford, 1997).

The seeds not always find in the soil favorable conditions for germination, especially in arid and semi-arid regions of the world, where the excess of salts in the soil have limited the agricultural production, mainly, in irrigated areas (Torres et al., 2000).

The increase on salt content in the substrate produces reduction of water potential, reducing the capacity of water absorption by the seeds, which directly influence the

\footnotetext{
${ }^{1}$ Submetido em 21/11/2004. Aceito para publicação 06/06/2005. Parte da dissertação de mestrado do primeiro autor.

${ }^{2}$ Bióloga, M.Sc., Professora do CEFET, Pça. 20 de setembro 455, 960000000, Pelotas, RS, giseladuarte@zipmail.com.br;

${ }^{3}$ Eng. Agr ${ }^{\circ}$., Ph.D., Professor Titular, Departamento de Botânica, IB/UFPel,
}

germination and seedling development (Rebouças et al., 1989).

Among the factors of the environment that influence seed germination, the water is one of the most important. The greater or smaller seed water absorption depends on the gradient of the water potential between the soil and the seed (Ribeiro et al., 2001). The reduction of soil water potential can delay or reduce germination rate of many vegetable species, therefore it influences the imbibition and the cellular elongation of the embryo (Bradford, 1990).

The vigor tests are used, mainly, to complement the information supplied by the germination test (Krzyzanowski et al., 1999). Thus, in vigor determination, the seeds are able to present different germination; therefore its performance depends on the capacity of the seeds to resist stress.

Due to the easiness and rapidity, the electric conductivity test became a standard procedure, in order to express the

Caixa Postal 354, 96010-900. Pelotas,RS;

${ }^{4}$ Eng. Agr ${ }^{\circ}$., Dr., Professor Adjunto, Departamento de Botânica, IB/UFPel, Caixa Postal 354, 96010-900, Pelotas,RS;

${ }^{5}$ Lic. Química, Mestrando do Programa de Pós-Graduação em Fisiologia Vegetal, Departamento de Botânica, IB/UFPel, Caixa Postal 354, 96010 900, Pelotas, RS. 
total concentration of salts for the classification and diagnose of waters destined to irrigation (Bernardo, 1995). The electric conductivity test aims to evaluate the amount of íons in the water and, indirectly, the vigor of the seeds, being based on the fact of that the vigor is related to the integrity of cellular membranes system of (Marcos Filho et al., 1987).

Salts with high solubility are most harmful to the seeds, because when absorbing water from substrate, also absorb the salts that, in excess, induce toxicity and, consequently, cause physiological disturbance to the seeds, producing decrease in the germination potential (Ferreira, 1997).

Experiments were carried out to evaluate physiological quality of the wheat seeds crs. BRS 179 and BRS 177 submitted the different sodium chloride concentrations.

\section{MATERIAL AND METHODS}

The present work was lead in the Seed Physiology Laboratory of the Department of Botany at the Federal University of Pelotas, using wheat seeds cultivars BRS 177 and BRS 179.

For germination test, seeds were imbibed during one hour in sodium chloride solutions with concentrations of 0,15 , 30,45 and $60 \mathrm{mM}$ of $\mathrm{NaCl}$. The test was carried out as specified by the Rules of Seeds Analysis (Brasil, 1992), using 400 seeds (four sub samples of 100 seeds) and three statistical replications, performing 1200 seeds per treatment, totalizing 6000 seeds for each cultivar. The substrate used was Germitest paper, previously humidified with distilled water, in the ratio of 2.5 times its initial mass (Brasil, 1992). The temperature of the germinator was set at $25 \pm 2^{\circ} \mathrm{C}$. Counts were done in the fourth day (first counting of germination) and eighth day (final counting of the germination). Germinated seeds presented radicle protrusion of $2 \mathrm{~mm}$. The results were expressed in germination percentage.
The electric conductivity was measured by a conductivity meter SCHOTT CG 853after three and 24 hours of imbibition, in four sub samples of 25 seeds placed by 1 hour in different solutions of $\mathrm{NaCl}$ (concentrations of $0,15,30,45$ and $60 \mathrm{mM}$ ), using three statistical replications for treatment. Then, seeds washed, dried, measured (dry mass) and placed in beaker with $80 \mathrm{ml}$ of distilled and deionized water (kept at $20^{\circ} \mathrm{C}$ with 24-hour antecedence), were taken to the germinator with constant temperature of $25 \pm 2^{\circ} \mathrm{C}$. The result was divided by the mass of the sample, express in $\mu \mathrm{S} \cdot \mathrm{m}^{-1} \cdot \mathrm{g}^{-1}$.

The germination speed index (GSI) was determined through a germination test, following the prescriptions for wheat in Popinigis (1985). The evaluations were performed daily at the same hour, for a period of eight days.

The experimental design used was entirely randomized in factorial scheme $(2 \times 5)$, with two wheat cultivars and five saline concentrations, with three replications. The average differences among treatments were compared by the Tukey test with $5 \%$ of probability.

\section{RESULTS AND DISCUSSION}

There was a significant deleterious effect (P£0.05) of the increase of salt concentration on germination (first counting and final), occurring the decrease in germination percentage in both cultivars, suggesting that salinity excess diminished the viability and the vigor of the seeds (Table 1).

Control seeds showed high germination, 96\% for cv. BRS 179 and 93.6\% for cv. BRS 177. In 15 and $30 \mathrm{mM}$ concentrations of $\mathrm{NaCl}$, germination, first count of germination and germination speed index tests did not showed significant differences between treatments, in both cultivars, however they revealed $(\mathrm{Pd}$ "0.05) more sensibility to $\mathrm{NaCl}$ in concentrations of 45 and $60 \mathrm{mM}$. These results agreed with Torres et al (2000) results found in cucumber seeds where

TABLE 1. Germination, first count of germination and germination speed index (GSI) of wheat seeds, cv BRS 179 and BRS 177 , in function of different saline concentrations.

\begin{tabular}{lcccccc}
\hline \multirow{2}{*}{$\mathrm{NaCl}$} & \multicolumn{2}{c}{ GERMINATION } & \multicolumn{2}{c}{ FIRST COUNT } & \multicolumn{2}{c}{ GSI } \\
\cline { 2 - 7 } & BRS 179 & BRS 177 & BRS 179 & BRS 177 & BRS 179 & BRS 177 \\
\hline ZERO & $96.0 \mathrm{aB}$ & $93.6 \mathrm{aB}$ & $93.4 \mathrm{aA}$ & $91.4 \mathrm{aB}$ & $45.5 \mathrm{aA}$ & $45.7 \mathrm{aB}$ \\
15 & $93.3 \mathrm{bA}$ & $93.1 \mathrm{aA}$ & $92.1 \mathrm{bA}$ & $91.2 \mathrm{aB}$ & $45.8 \mathrm{bA}$ & $45.4 \mathrm{bB}$ \\
30 & $93.3 \mathrm{bA}$ & $93.0 \mathrm{aA}$ & $92.0 \mathrm{bA}$ & $90.8 \mathrm{aB}$ & $45.6 \mathrm{bA}$ & $45.1 \mathrm{cB}$ \\
45 & $91.3 \mathrm{cA}$ & $89.7 \mathrm{bB}$ & $89.0 \mathrm{cA}$ & $89.0 \mathrm{bA}$ & $44.7 \mathrm{cA}$ & $44.3 \mathrm{~dB}$ \\
60 & $91.0 \mathrm{cA}$ & $89.3 \mathrm{bB}$ & $87.7 \mathrm{dA}$ & $87.0 \mathrm{cB}$ & $44.2 \mathrm{dA}$ & $43.8 \mathrm{eB}$ \\
\hline $\mathrm{CV}(\%)$ & 0.43 & 0.64 & 0.69 & 0.52 & 0.29 & 0.22 \\
\hline
\end{tabular}

Averages followed by the same letter in columns (concentration of $\mathrm{NaCl}$ ) and capital letters in rows (cultivars) do not differ at the $5 \%$ significance level by Tukey Test. 
gradual increase of $\mathrm{NaCl}$ in the substrate was harmful to germination. The effects of salinity can be related to the osmotic factor of the salt, limiting the hydration of the seeds, or to the toxic effect of the salt on the embryo and cells membranes of endosperm (Bliss et al., 1986). Also can be related to the restriction imposed on cell division and cellular elongation, as well as the immobilization of indispensable reserves to the sites where occurs the germination process (Ferreira and Rebouças, 1992).

In cereal seeds, barley and wheat, and also in tomato seeds, the sensibility to salt increases after germination (Maas and Hoffman, 1977). Similar results were found in seeds of oats and alfalfa, where the germination percentage reduces with the increase of the osmotic potential caused by the addition of salts (Popinigis, 1985).

The increment in the intensity of environmental stress leads, in general, to an increase in the germination time, affecting the percentage of germination of the seeds. Also water stress can reduce the percentage of germination speed in a great number of species, varying from those very sensible to the most resistant ones (Bewley and Black, 1985).

In general, wheat seeds cv. BRS 179 were more resistant to the imposed salinity than $\mathrm{cv}$. BRS 177 . The percentages of germination obtained in both wheat cultivars (Table 1) can be compared with the imbibition's curves presented in Figure 1. The imbibition over reduced water potentials diminishes the water content of the seeds, increases the duration of lag phase and delays the radicle emergency. The growth of radicle occurs only if the water content exceeds a critical level (Perez et al., 2001).

Both cultivars, BRS 179 and BRS 177, initiated germination after 300 minutes, presenting in the first count and final count of germination high indices of germinated seeds.

The germination speed index decreased with the increment of the saline concentration. Similar results were found by Damiani et al. (2003) and in rice seeds by Lima et al.(2005).

Capacity of water absorption of seeds was reduced according to the increment of salinity. These results can be explained by the salts in the imbibition water that reduced the osmotic potential of the solution, resulting in delaying time of imbibition of the seeds and, consequently, of seedling emergency (Ashraf and Iram, 2002). Similar results were obtained with Annona muricata submitted to the salinity (Silva, 1997).

The electric conductivity ( 3 hours) significantly increased
(Pd"0.05) in function of the increment of the saline concentration and between cultivars, suggesting that $\mathrm{NaCl}$ affected in a negative way the speed of rearrangement of cellular membranes, allowing the leaching of minerals salts, sugars, proteins and other components of the seed, tendency also observed in the 24 hours reading (Table 2).

The electric conductivity of BRS 177 was higher than

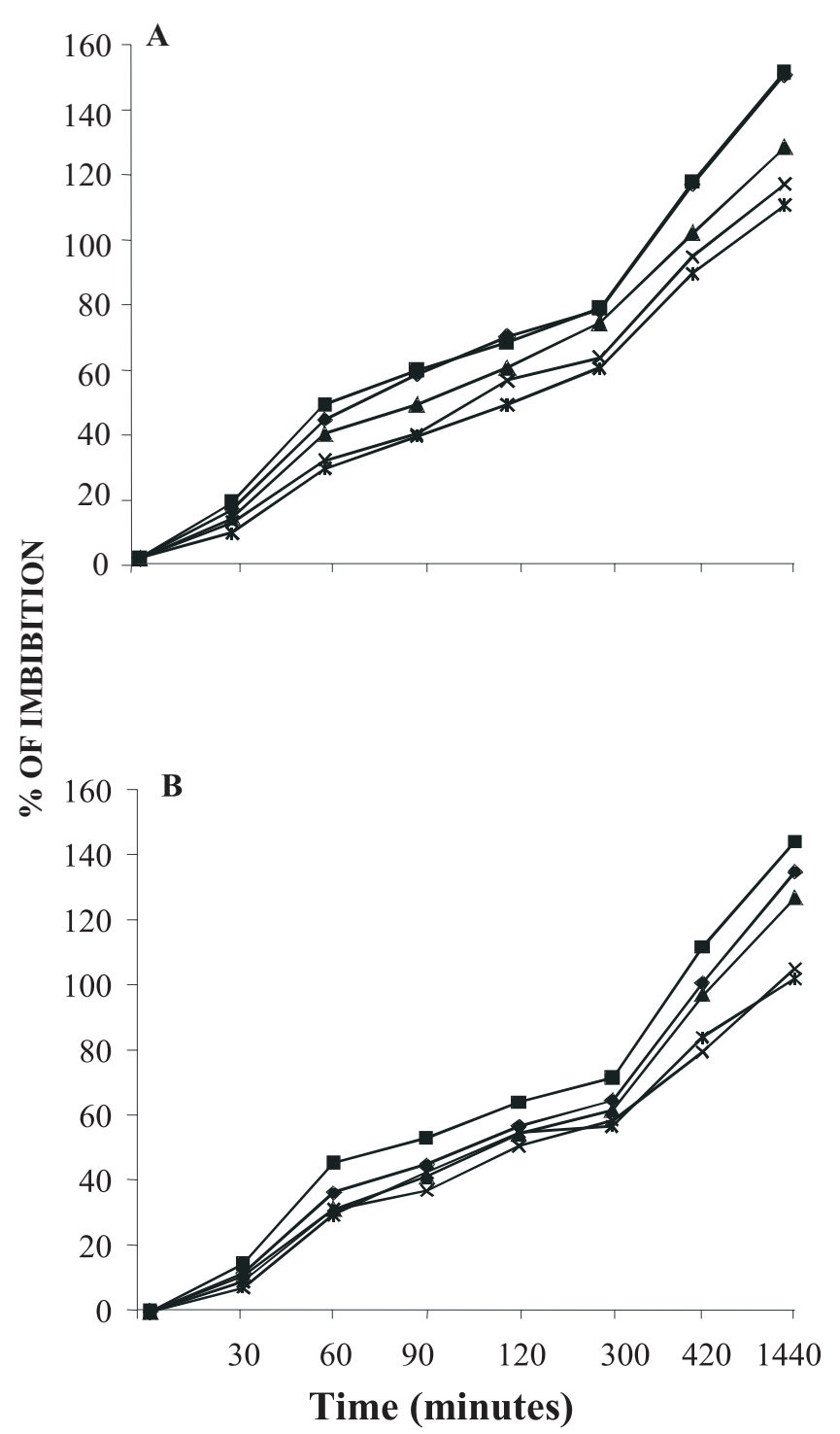

FIGURE 1. Imbibition curve of wheat seeds BRS 177 (A) and BRS 179 (B) submitted the different saline

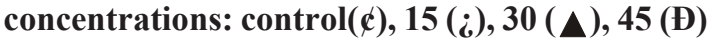
and $60(\mathrm{P}) \mathrm{mM}$ of $\mathrm{NaCl}$. 
TABLE 2. Electric conductivity after 3 and 24 hours of wheat seeds cv. BRS 177 and BRS 179, in function of different saline concentrations

\begin{tabular}{lcccc}
\hline & \multicolumn{3}{c}{ CONDUCTIVITY $\left(\mu \mathrm{N} \mathrm{m}^{-1} \mathrm{~g}^{-1}\right)$} \\
\hline \multirow{2}{*}{$\mathrm{NaCl}$ CONCENTRATION $(\mathrm{Mm})$} & \multicolumn{3}{c}{2 hours } & \multicolumn{2}{c}{ BRS 179 } & BRS 177 \\
\cline { 2 - 5 } ZERO & BRS 179 & BRS 177 & $2.19 \mathrm{~dB}$ & $2.46 \mathrm{eA}$ \\
15 & $1.92 \mathrm{eB}$ & $2.23 \mathrm{eA}$ & $2.79 \mathrm{cB}$ & $3.08 \mathrm{dA}$ \\
30 & $2.19 \mathrm{~dB}$ & $2.32 \mathrm{dA}$ & $3.12 \mathrm{bB}$ & $3.58 \mathrm{cA}$ \\
45 & $2.37 \mathrm{cB}$ & $2.88 \mathrm{cA}$ & $3.19 \mathrm{bB}$ & $4.06 \mathrm{bA}$ \\
60 & $2.56 \mathrm{bB}$ & $3.49 \mathrm{bA}$ & $3.37 \mathrm{aB}$ & $4.26 \mathrm{aA}$ \\
\hline $\mathrm{CV}(\%)$ & $2.99 \mathrm{aB}$ & $3.90 \mathrm{aA}$ & 0.96 & 0.52 \\
\hline
\end{tabular}

Averages followed by the same letter in columns (concentration of $\mathrm{NaCl}$ ) and capital letters in rows (cultivars) do not differ at the $5 \%$ significance level by Tukey Test.

the BRS 179, suggesting that the salt caused more damages to the integrity of membranes of the cultivar BRS 177.

\section{CONCLUSIONS}

The physiological quality of wheat seeds, cultivars BRS 179 and BRS 177, decrease with the increase of the salinity.

The wheat seeds cv. BRS 179 performs better than BRS 177 , mainly in higher salt concentrations ( ${ }^{3} 45 \mathrm{mM}$ of $\left.\mathrm{NaCl}\right)$.

The electric conductivity of wheat seeds increases in function of the increment of the saline concentrations.

\section{REFERENCES}

BECWAR, M.R.; STANWOOD, P.C.; ROOS, E.E. Rehydration effects on imbibitional leakage from desiccation-sensitive seeds. Plant Physiology, Rockville, v. 69, n.5, p. 1132-1135, 1982.

BERNARDO, S. Manual de Irrigação 6 ed. Viçosa: UFV, 1995. $657 \mathrm{p}$.

BEWLEY, J.D.; BLACK, M. Seeds: physiology of development and germination. New York: Plenum Press, 1985. 367p.

BLISS, R.D.; PLATT-ALOIA, K.A.; THOMPSON, W.W. Osmotic sensitivity in relation to salt sensitivity in germinating barley seeds. Plant, and Cell Environment, Oxford, v. 13, n. 1, p. 409418, 1986.

BRADFORD, K.J. A water relations analysis of seed germination rates. Plant Physiology, Lancaster, v. 94, n.3, p.840-849, 1990.

BRADFORD, K.J. The hydro time concept in seed germination and dormancy. In: $\quad$ ELLIS, R.H; BLACK, M. MURDOCH, A.J.; HONG, T.D. (Ed.). Basic and applied aspects of seed biology. Dordrecht: Kluver Academic Publishers, $1997 . \quad$ p.349-360.

BRASIL. Ministério de agricultura e reforma agrária. Regras para análise de sementes. Brasília: SNDV/ DNDV/CLAV. 1992.365p.

DAMIANI, C.R. Alterações bioquímicas e fisiológicas em sementes de trigo (Triticum aestivum L.) induzidas por reguladores de crescimento vegetal. Revista Brasileira de Agrociência,
Pelotas, v. 9, n. 4, p. 347-352, 2003.

FERREIRA, L.G. ; REBOUÇAS, M.A. Influência da hidratação/ desidratação de sementes de algodão na superação dos efeitos da salinidade na germinação. Pesquisa Agropecuária Brasileira, Brasília, v. 27, n.4, p.609-615, 1992.

FERREIRA, P.A. Aspectos físico-químicos do solo. In: GHEYI, H. R.; QUEIROZ, J. E. ; MEDEIROS, J. F. Manejo e controle da salinidade na agricultura irrigada. Campina Grande: UFPB/ SBEA, 1997. p.37-67.

KRZYZANOWSKI, F.C.; VIEIRA, R.D.; FRANÇA-NETO, J.B. Vigor de sementes: conceitos e testes. Londrina: ABRATES, 1999. 218 p.

LIMA, M.G.S.; LOPES, N. F.; MORAES, D.M.; ABREU, C.M. Germinação e vigor de sementes de arroz submetidas a estresse salino. Revista Brasileira de Sementes, Pelotas, v. 27 , n. 1 , p. 54 - 61,2005.

MAAS, E.V.; HOFFMAN, G.J. Crop salt tolerance-current assessment. ASCE Journal of Irrigation and Drainage Division, New York, v. 103, n.2, p.115-134, 1977.

MARCOS FILHO, J.; CÍCERO, S.M.; SILVA, W.R. Avaliação da qualidade fisiológica das sementes Piracicaba: FEALQ, 1987. 230 p.

PEREZ, S.C.J.G. de A.; FANTI, S.C.; CASALI, C.A. Salt stress and salt temperature interaction on the germination of Peltophorum dubium seeds. Journal of Tropical Forest Science, Kuala Lumpur, v. 13, n.1, p.44-61, 2001.

POPINIGIS, F. Fisiologia da semente. 2. ed. Brasília: AGIPLAN, 1985. 289p.

REBOUÇAS, M.A.; FAÇANHA, J.G.V.; FERREIRA, L.G.R.; PRISCO, J.T. Crescimento e conteúdo de N, P, K e Na em três cultivares de algodão sob condições de estresse salino. Revista Brasileira de Fisiologia Vegetal, Brasília, v.1, n.1, p.79- 85, 1989.

RIBEIRO, M.C.C.; MARQUES, M.B.; AMARO FILHO, J.A. Efeito da salinidade na germinação de sementes de quatro cultivares de girassol. Revista Brasileira de Sementes, Londrina, v.23, n.1, p.281-284, 2001.

SILVA, D.A. Efeitos de fontes e níveis de salinidade sobre a germinação e desenvolvimento de plântulas de graviola (Annona muricata L.). 1997. 64f. Dissertação (Mestrado em Manejo de 
Solo) - Universidade Federal da Paraiba, Areia, 1997.

SIMON, E.W.; RAJA-HARUN, R.M. Leakage during seed imbibition. Journal of Experimental Botany, Oxford, v. 23, n.77, p. 1076-1085, 1972.
TORRES, S.B.; VIEIRA, E.L.; MARCOS FILHO, J.M. Efeitos da salinidade na germinação e no desenvolvimento de plântulas de pepino. Revista Brasileira de Sementes, Londrina, v. 22, n. 2, p.39-44, 2000.

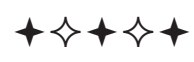

